\title{
PENGOLAHAN LIMBAH CAIR LABORATORIUM TEKNIK LINGKUNGAN DENGAN KOAGULASI DAN ADSORPSI UNTUK MENURUNKAN COD, Fe, DAN Pb
}

Mia Audiana ${ }^{11}$, Isna Apriani ${ }^{11}$, Ulli Kadaria ${ }^{1)}$

1) Program Studi Teknik Linkungan Jurusan teknik Sipil Fakultas Teknik Universitas Tanjungpura, Pontianak Email :audiana_mi@yahoo.co.id

\begin{abstract}
ABSTRAK
Limbah Laboratorium merupakan salah satu limbah yang banyak mengandung senyawa organik maupun anorganik. Laboratorium Teknik Lingkungan adalah Laboratorium yang belum mempunyai pengolahan limbah, sehingga limbah cair yang dihasilkan dari berbagai praktikum dikumpulkan di dalam suatu wadah. Hal ini mengakibatkan terjadinya penumpukkan limbah. Pada penelitian ini dilakukan pengolahan limbah cair Laboratorium Lingkungan dengan kombinasi proses koagulasi dan adsorpsi untuk menurunkan nilai $\mathrm{COD}$, ion logam $\mathrm{Fe}^{2+}$, dan ion logam $\mathrm{Pb}^{2+}$ yang melebihi baku mutu menurut PERMEN LH No.5 Th 2014. Penelitian ini bertujuan untuk mengetahui kadar COD, ion logam $\mathrm{Fe}^{2+}$ dan ion logam $\mathrm{Pb}^{2+}$ pada limbah Laboratorium Lingkungan serta mengetahui efisiensi pengolahan limbah dengan menggunakan kombinasi proses koagulasi dan adsorpsi. Berdasarkan hasil uji pendahuluan, $\mathrm{COD}$, io logam $\mathrm{Fe}^{2+}$ dan ion logam $\mathrm{Pb}^{2+}$ yang terkandung di dalam limbah Laboratorium Lingkungan adalah 611,4 mg/l, 19,4 mg/l, dan 22,9 mg/l. Sedangkan Baku Mutu yang diperbolehkan berdasarkan PERMEN LH No.5 Th 2014 adalah COD $100 \mathrm{mg} / \mathrm{l}$, ion logam $\mathrm{Fe}^{2+} 5 \mathrm{mg} / \mathrm{l}$, dan ion logam $\mathrm{Pb}^{2+}$ $0,1 \mathrm{mg} / \mathrm{l}$. Pengolahan limbah cair Laboratorium dilakukan dengan kombinasi proses koagulasi menggunakan tawas dan adsorpsi menggunakan zeolit dan karbon aktif. Pengolahan ini dilakukan dengan sistem batch dan dalam skala laboratorium. Dosis tawas yang digunakan sebanyak 0,31 g sedangkan zeolit dan karbon aktif yang digunakan masing-masing $125 \mathrm{~g}$. Pengujian dilakukan secara duplo untuk mendapatkan hasil yang akurat. Efisiensi dari pengolahan limbah cair Laboratorium Lingkungan dengan kombinasi proses koagulasi dan adsorpsi adalah COD sebesar 59,81\% dari 611,4 $\mathrm{mg} / \mathrm{l}$ menjadi $245,7 \mathrm{mg} / \mathrm{l}$, ion logam $\mathrm{Fe}^{2+}$ sebesar $62,25 \%$ dari $19,4 \mathrm{mg} / \mathrm{l}$ menjadi $7,324 \mathrm{mg} / \mathrm{l}$, serta ion logam $\mathrm{Pb}^{2+}$ sebesar $71,13 \%$ dari $22,9 \mathrm{mg} / \mathrm{l}$ menjadi $6,612 \mathrm{mg} / \mathrm{l}$.
\end{abstract}

Kata kunci: adsorpsi, koagulasi dan limbah cair laboratorium.

\section{ABSTRACK}

Laboratory waste is one of wastewater which contains organic and inorganic matters. Environmental Engineering Laboratory currently does not have wastewater treatment plant, so waste from various laboratory practice just being collected in a container. This resulted in accumulation of wastewater. In this research, waste water from Environmental Engineering Laboratory treated by combination of coagulation and adsorption process to reduce $\mathrm{COD}, \mathrm{Fe}$, and $\mathrm{Pb}$ level that exceeded the waste water quality standard according to PERMEN LH No.5 in 2014. This research aim to find out the level of COD, $\mathrm{Fe}$, and $\mathrm{Pb}$ on Environmental Engineering Laboratory waste water, and to determine efficiency of waste water treatment with combination of coagulation and adsorption process. Based on preliminary test result, level of $\mathrm{COD}, \mathrm{Fe}$, and $\mathrm{Pb}$ on Environmental Engineering Laboratory waste water is $611,4 \mathrm{mg} / \mathrm{l}$, $19,4 \mathrm{mg} / \mathrm{l}$, and 22,9 $\mathrm{mg} / \mathrm{l}$. Meanwhile, the waste water quality standard according to PERMEN LH No.5 in 2014 is $100 \mathrm{mg} / \mathrm{l}$ for COD, $5 \mathrm{mg} / \mathrm{l}$ dor Fe, and 0,1 mg/l for Pb. Laboratory waste water treatment was conducted in combination of coagulation with use of alum and adsorption with use of zeolite and active carbon. This treatment conducted in batch system and in laboratory scale. Dosage for alum was 0,31 grams, whilst dosage for zeolite and active carbon were 125 grams each. In order to get accurate result, the test done with duplo. The efficiency of environmental engineering laboratory waste water treatment with combination of coagulation and adsorption process are 59,81\% for COD (with level from $611,4 \mathrm{mg} / \mathrm{l}$ to $245,7 \mathrm{mg} / \mathrm{l}), 62,25 \%$ for Fe (with level from $19,4 \mathrm{mg} / \mathrm{l}$ to $7,324 \mathrm{mg} / \mathrm{ll}$ ), and $71,13 \% \mathrm{for} \mathrm{Pb}$ (with level from $22,9 \mathrm{mg} / \mathrm{l}$ to $6,612 \mathrm{mg} / \mathrm{l}$ ).

Keyword: adsorption, coagulation, laboratory waste water 


\section{Pendahuluan}

Limbah laboratorium merupakan salah satu limbah yang banyak mengandung senyawa organik dan anorganik. Limbah tersebut merupakan sisa bahan kimia yang digunakan dalam praktikum. Limbah cair Laboratorium Lingkungan Fakultas Teknik Universitas Tanjungpura yang dihasilkan dari kegiatan praktikum dikumpulkan dalam suatu wadah dan belum dilakukan pengolahan, sehingga terjadi penumpukkan. Berdasarkan zat yang terkandung di dalam limbah cair laboratorium secara kolektif dan dalam kurun waktu yang lama apabila dibuang langsung ke lingkungan akan mencemari lingkungan, seperti merusak struktur tanah, mengancam kelangsungan hidup ekosistem air maupun darat, serta berdampak bagi kesehatan manusia. Oleh karena itu pada penelitian ini akan dibuat pengolahan limbah cair Laboratorium Lingkungan.

Limbah laboratorium yang dihasilkan merupakan campuran dari berbagai reaksi dan sisa sampel praktikum dan penelitian dengan parameter yang melebihi baku mutu berdasarkan Peraturan Menteri Lingkungan Hidup Republik Indonesia No.5 Tahun 2014 yaitu $\mathrm{COD}, \mathrm{Pb}, \mathrm{Fe}$. Berdasarkan uji pendahuluan nilai parameter tersebut yaitu COD 611,4 mg/L, pH 3,16, Fe 19,40 mg/L, dan $\mathrm{Pb} 22,90 \mathrm{mg} / \mathrm{L}$. Nilai parameter yang diperbolehkan yaitu COD 100 $\mathrm{mg} / \mathrm{L}$, pH 6,0-9,0, Fe $5 \mathrm{mg} / \mathrm{L}$, dan Pb 0,1 mg/L. Berdasarkan penelitian Wardhani, dkk (2012), tawas $\mathrm{Al}_{2}\left(\mathrm{SO}_{4}\right)_{3}$ mampu menurunkan kadar Chemical Oxygen Demands (COD) 64,07\% dari $811,19 \mathrm{mg} / \mathrm{l}$ menjadi $170,67 \mathrm{mg} / \mathrm{l}$ pada limbah industri penyamakan kulit. Adsorben zeolit mampu menurunkan logam yang terkandung dalam air lindi yaitu Fe sebesar 62,728\% dari $12,668 \mathrm{mg} / \mathrm{I}$ menjadi 7,948 mg/l (Larasati. dkk. 2014) serta logam Pb sebesar 73,75\% dari 2,29 $\mathrm{mg} / \mathrm{l}$ menjadi 0,39 mg/l (Susanawati, dkk. 2011). Menurut penelitian Fajarwati, dkk (2012) karbon aktif mampu menurunkan logam besi sebesar 59,64\% dari 3,03 mg/l menjadi 1,22 $\mathrm{mg} / \mathrm{l}$, dan menaikkan $\mathrm{pH}$ dari 5,1 menjadi 9,33, serta dapat menyerap warna dalam pengolahan air tanah. Oleh karena itu pada penelitian ini akan dilakukan pengolahan limbah Laboratorium Lingkungan dengan kombinasi proses koagulasi menggunakan tawas dan proses adsorpsi menggunakan zeolit dan karbon aktif guna menurunkan parameter tersebut. Tujuan dari penelitian ini adalah untuk mengetahui nilai parameter ( $\mathrm{COD}, \mathrm{Pb}, \mathrm{Fe}$ ) pada limbah Laboratorium Lingkungan serta mengetahui efektivitas penurunan parameter limbah dengan pengolahan menggunakan kombinasi proses koagulasi dan adsorpsi.

\section{Metodologi}

Penelitian ini dilakukan selama 1 minggu yaitu pada bulan Mei 2016. Penelitian dilakukan di dua tempat yaitu pembuatan dan pengoperasian alat dilakukan di Laboratorium Lingkungan Prodi Teknik Lingkungan Fakultas Teknik Universitas Tanjungpura, serta pengujian parameter (COD, pH, Fe, Pb) dilakukan di Laboratorium Kualitas dan Kesehatan Lahan Fakultas Pertanian Universitas Tanjungpura.

Alat yang digunakan dalam penelitian ini adalah tiga buah gelas beaker ukuran $100 \mathrm{ml}$, reaktor berukuran 1,5 L sebanyak 4 buah, pH meter, serta Spektrofotometer Serapan Atom atau Atomic Absorption Spectrophotometer (AAS). Sedangkan bahan yang digunakan adalah tawas, zeolit, karbon aktif, serta limbah Laboratorium Teknik Lingkungan. Limbah laboratorium yang digunakan sebanyak $1,8 \mathrm{~L}, 03 \mathrm{~L}$ untuk jartest, 0,5 L untuk pengujian 
sebelum pengolahan, $1 \mathrm{~L}$ untuk pengolahan, dan $0,5 \mathrm{~L}$ dari $1 \mathrm{~L}$ untuk pengujian sesudah pengolahan.

Sebelum dilakukan pengolahan, terutama dilakukan uji jartest pada limbah untuk menetukan konsentrasi koagulan yang digunakan. Variasi konsentrasi koagulan yang digunakan yaitu 0,15 g, 0,17 g, dan 0,19 g untuk $100 \mathrm{ml}$ air limbah. kecepatan pengadukan yang digunakan adalah $100 \mathrm{rpm}$ sebagai pengadukan cepat selama 1 menit, $40 \mathrm{rpm}$ sebagai pengadukan lambat selama 15 menit, dan 30 menit tanpa pengadukan.

Jenis penelitian ini adalah studi eksperimental berupa perancangan alat pengolahan limbah laboratorium menggunakan kombinasi proses koagulasi dan adsorpsi dengan sistem batch dan dilakukan dalam skala laboratorium. Koagulan yang digunakan pada proses koagulasi adalah tawas yang berfungsi untuk menurunkan kadar organik yaitu COD yang terdapat pada limbah. Sedangkan adsorben yang digunakan adalah zeolit dan karbon aktif yang berfungsi untuk menurunkan logam $\mathrm{Fe}$ dan $\mathrm{Pb}$ pada limbah. Dengan merancang alat pengolahan limbah laboratorium dengan kombinasi proses koagulasi dan adsorpsi diharapkan dapat menurunkan kadar $\mathrm{COD}$, logam $\mathrm{Fe}$, dan logam $\mathrm{Pb}$ yang terdapat pada limbah cair Laboratorium Lingkungan. Rancangan penelitian dilakukan dengan pre-test dan post-test, dimana dilakukan pengujian kadar COD dengan metode Closed Reflux, serta logam Fe dan logam $\mathrm{Pb}$ dengan metode AAS sebelum dan sesudah melalui pengolahan. Kualitas air limbah laboratorium dibandingkan dengan Peraturan Menteri Lingkungan Hidup Republik Indonesia No.5 Tahun 2014 tentang Baku Mutu Air Limbah.

Pada pengolahan, Limbah laboratorium sebanyak $1 \mathrm{~L}$ dimasukkan ke bak koagulasi yang kemudian di tambahkan koagulan dan dilakukan pengadukan. Dari bak koagulasi limbah dialirkan ke bak adsorbsi yang berisi zeolit dan karbon aktif masing-masing $125 \mathrm{~g}$ (Azamia, 2012). Kemudian limbah didiamkan di dalam bak adsorpsi selama 24 jam. Limbah yang berasal dari bak adsorbsi ditampung di dalam bak outlet yang kemudian akan diuji guna mengetahui penurunan parameter (COD, $\mathrm{pH}, \mathrm{Fe}$, dan $\mathrm{Pb}$ ) pada limbah tersebut. Pengujian dilakukan secara duplo, yaitu dilakukan dua pengolahan dengan perlakuan yang sama.

Analisis data dilakukan dengan metode deskriftif komperatif, dimana kualitas air limbah laboratorium yang telah dilakukan pengolahan dibandingkan dengan kualitas air limbah laboratorium sebelum dilakukan pengolahan untuk mendapatkan nilai efektivitas yang disajikan dalam bentuk tabel.

\section{Hasil dan Pembahasan}

Limbah yang digunakan dalam penelitian ini adalah limbah Laboratorium Lingkungan Fakultas Teknik Universitas Tanjungpura. Limbah tersebut merupakan hasil buangan yang ditampung dari berbagai macam aktivitas praktikum yang dilakukan di Laboratorium Lingkungan. Bedasarkan uji pendahuluan, limbah Laboratorium Lingkungan memiliki kadar logam $\mathrm{Fe}$, logam $\mathrm{Pb}$, dan $\mathrm{COD}$ yang melebihi baku mutu seperti pada Tabel 1 berikut ini. 
Tabel 1 Kandungan Limbah Laboratorium Lingkungan

\begin{tabular}{cccc}
\hline Parameter & Satuan & Hasil Analisis & Baku Mutu \\
\hline $\mathrm{COD}$ & $\mathrm{mg} / \mathrm{l}$ & 611.4 & 100 \\
Logam Fe & $\mathrm{mg} / \mathrm{l}$ & 19.4 & 5 \\
Logam Pb & $\mathrm{mg} / \mathrm{l}$ & 22.9 & 0.1
\end{tabular}

*: PERMEN LH No. 5 Th. 2014

\section{a. Penentuan Dosis Kogulan}

Proses pengolahan dimulai dengan mencari dosis optimum koagulan tawas, denga variasi tawas yaitu $0,15 \mathrm{~g}, 0,17 \mathrm{~g}$, dan $0,19 \mathrm{~g}$. Setelah dilakukan pengadukan pada limbah dengan dosis tawas $0,15 \mathrm{~g}, 0,17 \mathrm{~g}$, dan $0,19 \mathrm{~g}$ tidak terdapat flok-flok yang terbentuk pada limbah tersebut, serta limbah masih terlihat keruh. Hal ini disebabkan kurangnya dosis tawas untuk volum limbah Laboratorium Lingkungan yang digunakan. Tawas tidak mampu menetralkan koloid yang terdapat di dalam suatu volume limbah, sehingga masih terdapat koloid serta limbah terlihat keruh. Oleh karena tidak didapatkan dosis optimum tawas pada dosis $0,15 \mathrm{~g}, 0,17 \mathrm{~g}$, dan $0,19 \mathrm{~g}$, maka dilakukan penentuan dosis optimum yang lebih tepat yaitu sebesar $0,1 \mathrm{~g}, 0,2 \mathrm{~g}$, dan 0,3 g. Dari penentuan dosis tersebut didapat nilai kekeruhan seperti pada Tabel 2 dan Gambar 1 berikut.

Tabel 2 Pengaruh Dosis Koagulan Terhadap Nilai Kekeruhan

\begin{tabular}{cc}
\hline Dosis Koagulan & Kekeruhan (NTU) \\
\hline 0.1 & 41.7 \\
0.2 & 24.8 \\
0.3 & 23.8 \\
\hline
\end{tabular}




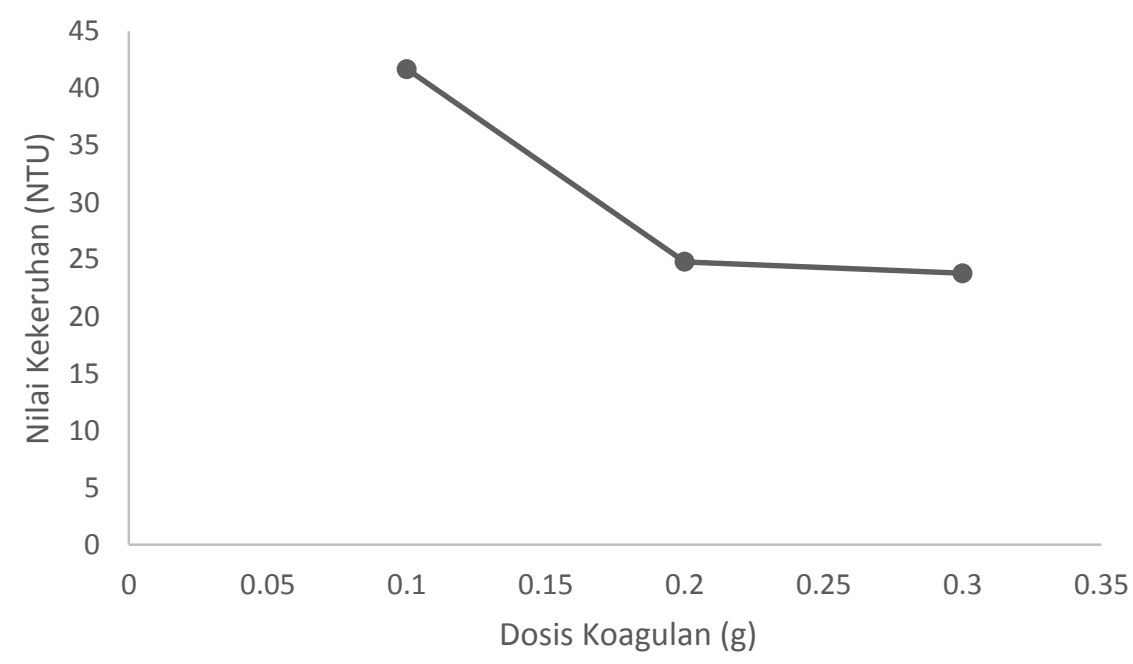

Gambar 1 Grafik Pengaruh Dosis Tawas Terhadap Nilai Kekeruhan

Dari Gambar 1 dapat dilihat bahwa semakin banyak dosis koagulan yang digunakan maka nilai kekeruhan semakin kecil. Hal ini dikarenakan pada proses jartest terjadi proses koagulasi dan flokulasi, dimana pada proses koagulasi terjadi destabilisasi koloid dan partikel dalam limbah yang disebabkan penambahan koagulan tawas. Proses destabilisasi terjadi karena koagulan tawas yang ditambahkan ke dalam limbah terurai menjadi ion positif dan negatif, yang kemudian dapat menetralkan partikel koloid dan mengikat partikel tersebut sehingga membentuk flok. Flok yang terbentuk semakin lama akan semakin membesar dan mengendap berdasarkan gaya gravitasi (Sutapa, 2014). Mengendapnya flok tersebut mengakibatkan kekeruhan pada limbah menjadi turun.

Setelah mengetahui dosis koagulan yang memiliki nilai kekeruhan terendah adalah $0,3 \mathrm{~g}$, maka dilakukan pengujian kekeruhan untuk dosis tawas antara $0,28 \mathrm{~g}$ sampai dengan 0,33 g guna mencari dosis optimum dari tawas. Adapun nilai kekeruhan yang didapat adalah seperti pada tabel berikut.

Tabel 3 Pengaruh Dosis Koagulan Terhadap Nilai Kekeruhan

\begin{tabular}{cc}
\hline Dosis Koagulan & Kekeruhan (NTU) \\
\hline 0.28 & 46.3 \\
0.29 & 23.1 \\
0.3 & 23.8 \\
0.31 & 22.5 \\
0.32 & 24.8 \\
0.33 & 23.7 \\
\hline
\end{tabular}

Sumber: Hasil Analisis, 2016 
Dari tabel diatas maka dapat dilihat grafik kekeruhan dari masing-masing dosis tawas seperti pada gambar berikut.

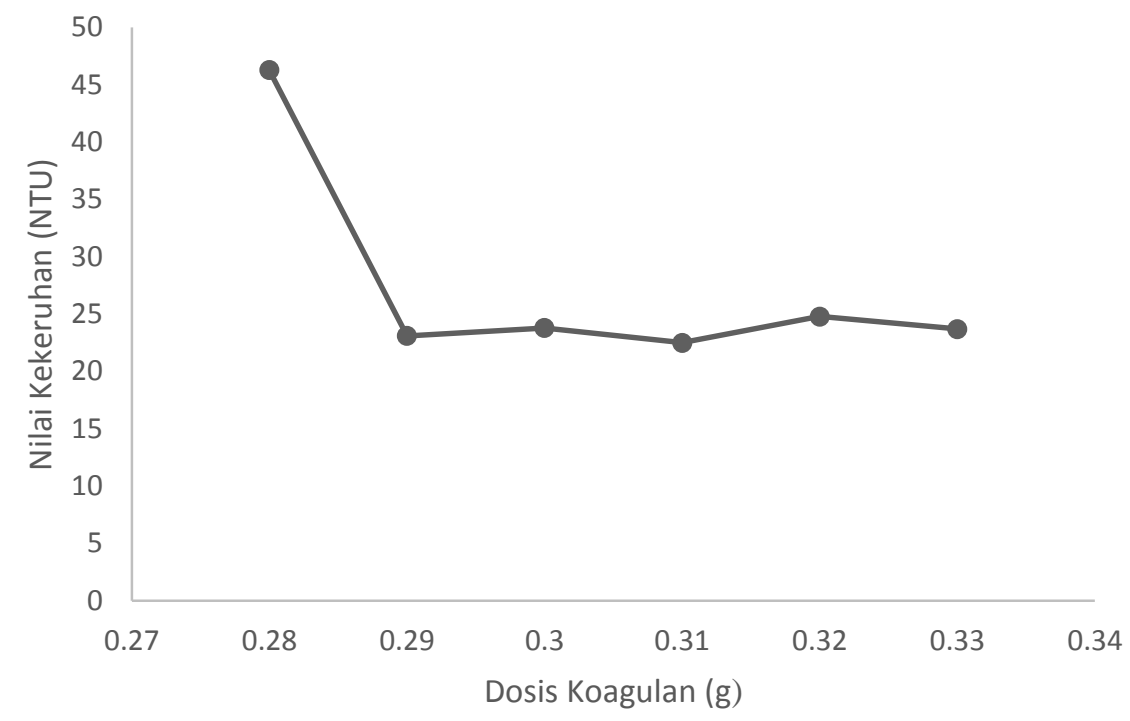

Gambar 2 Grafik Pengaruh Dosis Tawas Terhadap Nilai Kekeruhan

Berdasarkan Gambar 2 dapat dilihat bahwa terjadi ketidak stabilan penurunan kekeruhan, tetapi nilai kekeruhan terendah terdapat pada dosis koagulan 0,31 gr. Ketidak stabilan ini dikarenakan koagulan tawas yang digunakan mengalami kejenuhan, sehingga tidak dapat menurunkan kekeruhan secara optimal. Selain itu pH limbah juga berpengaruh, dimana semakin banyak dosis koagulan tawas yang digunakan maka $\mathrm{pH}$ limbah akan semakin asam/turun yang menyebabkan tawas tidak bisa bekerja lebih efektif (Aziz. dkk, 2013).

\section{b. Efisiensi Penurunan}

Tabel 4 Hasil dari pengolahan yang telah dilakukan dapat dilihat pada tabel berikut.

\begin{tabular}{ccccrc}
\hline Parameter & Satuan & $\begin{array}{c}\text { Konsentrasi Parameter } \\
\text { Sebelum } \\
\text { Pengolahan }\end{array}$ & $\begin{array}{c}\text { Sesudah } \\
\text { Pengolahan }\end{array}$ & $\begin{array}{c}\text { Baku } \\
\text { Mutu }\end{array}$ & $\begin{array}{c}\text { Efisiensi } \\
\text { Penurunan (\%) }\end{array}$ \\
\hline $\mathrm{COD}$ & $\mathrm{mg} / \mathrm{L}$ & 611.4 & 245.7 & 100 & 59.81 \\
$\mathrm{Fe}$ & $\mathrm{mg} / \mathrm{L}$ & 19.4 & 7.324 & 5 & 62.25 \\
$\mathrm{~Pb}$ & $\mathrm{mg} / \mathrm{L}$ & 22.9 & 6.612 & 0.1 & 71.13 \\
\hline
\end{tabular}

*: PERMEN LH RI No.5 Th. 2014

- Tawas

Tawas dapat mengurangi zat-zat- tersuspensi yang terdapat dala limbah, baik bahan kimia organik maupun anorganik. Dengan terjadinya penurunan bahan kimia organik maupun anorganik tersebutlah yang kemudian menurunkan nilai COD pada limbah (Aziz, dkk. 2013). 
Hal ini disebabkan tawas $\left(\mathrm{Al}_{2}\left(\mathrm{SO}_{4}\right)_{3}\right)$ yang ditambahkan ke dalam air, kation Al pada tawas akan mengalami reaksi hidrolisis untuk membentuk spesies Al terlarut atau endapan alumunium hidroksida. Spesies Al terlarut yang terbentuk berupa monomer dan beberapa diantaranya bermuatan positif yang dapat menetralkan partikel koloid yang bermuatan negatif. Kandungan organik yang bersifat negatif cenderung teradsorpsi dan terperangkap dalam endapan alumunium hidroksida (Sutapa, 2014). Hal ini yang menyebabkan nilai COD pada limbah menjadi turun.

Pada penelitian Aziz, dkk (2013) penambahan tawas $\left(\mathrm{Al}_{2}\left(\mathrm{SO}_{4}\right)_{3}\right.$ pada air Sungai Lambidaro mengakibatkan nilai COD menjadi turun yaitu dari $19 \mathrm{mg} / \mathrm{l}$ menjadi $2 \mathrm{mg} / \mathrm{l}$, sedangkan pada penelitian ini penurunan COD menggunakan tawas jauh lebih besar yaiu dari $611,4 \mathrm{mg} / \mathrm{l}$ menjadi $245,7 \mathrm{mg} / \mathrm{l}$. Hal ini dikarenakan jumlah tawas yang digunakan pada penelitian ini lebih besar dibandingkan penelitian sebelumnya, sehingga proses pengikatan bahan kimia organik maupun anorganik yang terdapat pada limbah menjadi lebih besar, yang mengakibatkan terjadinya penurunan COD lebih besar.

Penambahan tawas pada proses koagulasi menyebabkan $\mathrm{pH}$ limbah menjadi lebih asam, dimana $\mathrm{pH}$ awal limbah 3,16 menjadi 1,82 . Hal ini dikarenakan tawas yang apabila dilarutkan dalam air akan melepaskan lebih banyak $\mathrm{H}^{+}$yang menyebabkan $\mathrm{pH}$ limbah semakin menurun (Aziz, dkk. 2013). Adapun reaksi yang terjadi adalah sebagai berikut.

$$
\mathrm{Al}_{2}\left(\mathrm{SO}_{4}\right)_{3}+6 \mathrm{H}_{2} \mathrm{O} \longrightarrow 2 \mathrm{Al}(\mathrm{OH})_{3}+6 \mathrm{H}^{+}+\mathrm{SO}_{4}{ }^{2-}
$$

Penurunan $\mathrm{pH}$ yang terjadi dapat mempengaruhi kinerja dari tawas dalam menurunkan partikel-partikel pencemar yang terdapat pada limbah. Tawas dapat bekerja secara optimal pada pH 6-7,8 (Nurlina, dkk. 2015). pH limbah laboratorium yang asam menyebabkan tawas tidak bisa bekerja secara optimal. Oleh karena itu nilai COD, logam Fe, serta logam $\mathrm{Pb}$ masih berada di atas baku mutu yang telah ditentukan.

- Zeolit

Proses adsorpsi menggunakan zeolit dan karbon aktif berfungsi untuk menurunkan ion logam $\mathrm{Pb}^{2+}$ yang terdapat pada limbah. Penurunan ion logam $\mathrm{Pb}^{2+}$ dengan proses adsorpsi terjadi karena zeolit dapat berperan sebagai penjerap/adsorben. Zeolit yang diaktivasi bersifat dehidrasi dan akan memiliki pori-pori yang terbuka. Semakin luas pori-pori zeolit maka akan semakin banyak adsorbat yang teradsorpsi (Azamia, 2012). Pada proses penjerapan menggunakan zeolit, ion logam $\mathrm{Pb}^{2+}$ yang terdapat pada limbah terjerap oleh pori permukaan zeolit dan bersubstitusi dengan kation $\mathrm{H}^{+}$yang terdapat pada permukaan zeolit seperti pada reaksi berikut ini.

$$
\text { Zeolit }-\mathrm{H}^{+}+\mathrm{Pb}^{2+} \longrightarrow \text { Zeolit }-\mathrm{Pb}^{2+}+\mathrm{H}^{+} \text {(Prayitno, 2006). }
$$

Dari reaksi tersebut dapat dilihat bahwa terjadi pertukaran ion antara ion logam $\mathrm{Pb}^{2+}$ dengan kation $\mathrm{H}^{+}$yang menyebabkan ion logam $\mathrm{Pb}^{2+}$ terperangkap di dalam pori zeolit. Hal ini dikarenakan permukaan silika $\left(\mathrm{SiO}_{2}\right)$ mempunyai afinitas yang tinggi terhadap ion logam $\mathrm{Pb}^{2+}$. Ion pusat silika $\left(\mathrm{Si}^{4+}\right)$ mempunyai afinitas yang kuat terhadap elektron (mudah menangkap elektron). Atom oksigen yang berikatan dengan ion silika yang mempunyai sifat kebasaan yang rendah dan membuat permukaan silika bersifat asam lemah. Atom oksigen 
pada permukaan silika bebas bereaksi dengan air membetuk grup silanol (SiOH). Bentuk oksida yang lain juga bebas bereaksi dengan air membentuk hidroksida. Ion $\mathrm{H}^{+}$pada bentuk hidroksida akan melemah dan mudah lepas dan mengakibatkan ion logam $\mathrm{Pb}^{2+}$ akan terikat dan teradsorpsi secara kuat (Setiaka, dkk. 2010). Hal ini yang menyebabkan kadar Pb pada limbah menjadi turun. Sedangkan kation $\mathrm{H}^{+}$yang terdapat pada permukaan zeolit terlepas dan menyebabkan $\mathrm{pH}$ limbah menjadi asam.

Berdasarkan penelitian sebelumnya (iswanto, 2016) pengolahan limbah percetakan dengan menggunakan zeolit alam teraktivasi mampu menurunkan kadar timbal pada limbah sebesar $52 \%$, sedangkan pada penilitian ini penurunan logam Pb lebih besar yaitu $71,13 \%$. Hal ini dikarenakan waktu kontak limbah dengan adsorben pada penelitian terdahulu lebih singkat dibandingkan penelitian ini yaitu selama 60 menit, sedangkan pada penelitian ini waktu kontak yang digunakan 24 jam. Lamanya waktu kontak limbah dengan adsorben pada penelitian ini mengakibatkan penurunan ion logam $\mathrm{Pb}$ menjadi besar, karena suatu adsorben memerlukan waktu untuk mencapai kesetimbangan dalam menjerap beban pencemar.

\section{- $\quad$ Karbon aktif.}

Selain zeolit, adsorben yang digunakan dalam proses adsorpsi pada pengolahan limbah Laboratorium adalah karbon aktif. Karbon aktif yang diaktivasi secara fisik yaitu dengan pencucian dan pemanasan mempunyai pori-pori yang terbuka dan memiliki rongga, dimana rongga tersebut mampu menjerap sejumlah molekul-molekul yang ukurannya lebih kecil atau sama dengan ukuran rongga karbon aktif tersebut (Khimayah, 2015).

Proses adsorpsi yang terjadi pada karbon aktif yaitu proses adsorpsi secara fisika, dimana proses penjerapan ion logam $\mathrm{Fe}^{2+}$ terjadi pada permukaan karbon aktif. Dengan adanya gaya Van Der Waals pada pori-pori karbon aktif maka partikel pencemar yang terdapat pada limbah tertarik dan terperangkap pada pori-pori karbon aktif (Hendra, 2008), sehingga ion logam $\mathrm{Fe}^{2+}$ pada limbah menjadi berkurang.

Berdasarkan penelitian Fajarwati (2012) karbon akif mampu menurunkan logam Fe pada pengolahan air tanah sebesar $59,64 \%$ dari $3,03 \mathrm{mg} / \mathrm{l}$ menjadi $1,22 \mathrm{mg} / \mathrm{l}$, sedangkan pada penelitian ini penurunan logam Fe terjadi sebesar $62,25 \%$ dari 19,4 menjadi $7,324 \mathrm{mg} / \mathrm{l}$. Hal ini dikarenakan pada penelitian Fajarwati (2012) sistem yang digunakan pada pengolahan adalah sistem continue sehingga waktu kontak air dengan adsorben tidak lama. Sedangkan pada penelitian ini, menggunakan sistem batch, dimana waktu kontak antara limbah dan adsorben lebih lama dibandingkan penelitian Fajarwati (2012), karena suatu adsorben memerlukan waktu untuk mencapai kesetimbangan dalam menjerap beban pencemar.

Sedikitnya jumlah karbon aktif yang digunakan dalam proses adsorpsi merupakan faktor yang menyebabkan logam Fe pada limbah masih berada di atas baku mutu yang telah ditentukan. Selain itu ukuran karbon aktif yang digunakan pada penelitian ini tidak sama juga dapat mempengaruhi luas permukaan pori-pori karbon aktif. Semakin besar pori-pori karbon aktif, maka semakin banyak pula partikel yang teradsorpsi. Hal ini yang menyebabkan nilai $\mathrm{COD}$, logam $\mathrm{Fe}$, dan logam $\mathrm{Pb}$ pada limbah masih berada di atas baku mutu. 
a. Kesimpulan

- Limbah Laboratorium Lingkungan Prodi Teknik Lingkungan Fakultas Teknik Universitas Tanjungpura mengandung COD 611,4 mg/l, logam Fe 19,40 mg/l, dan logam $\mathrm{Pb} 22,90 \mathrm{mg} / \mathrm{l}$, serta $\mathrm{pH} 3,16$.

- $\quad$ Pegolahan Limbah Laboratorium Prodi Teknik Lingkungan Fakultas Teknik Universitas Tanjungpura dengan kombinasi proses koagulasi dan adsorpsi mampu menurunkan COD dengan efisiensi sebesar 59,81\% dari $6114 \mathrm{mg} / \mathrm{I}$ menjadi $245,7 \mathrm{mg} / \mathrm{l}$, logam Fe 62,25\% dari $194 \mathrm{mg} / \mathrm{l}$ menjadi 7,324 mg/l, dan logam $\mathrm{Pb} 71,13 \%$ dari 22,9 mg/l menjadi $6,612 \mathrm{mg} / \mathrm{l}$. Sedangkan $\mathrm{pH}$ limbah menjadi lebih asam yaitu 1,82.

b. Saran

Setelah dilakukan pengolahan limbah cair Laboratorium Teknik Lingkungan nilai parameter yang diujikan masih berada di atas baku mutu menurut PERMEN LH No. 5 Th. 2014. Sehingga perlu dilakukan uji lanjutan pengolahan limbah cair Laboratorium Teknik Lingkungan dengan melakukan netralisasi limbah sebelum pengolahan karena $\mathrm{pH}$ limbah Laboratorium Lingkungan sangat asam yaitu 3,16.

\section{Ucapan Terimakasih}

Dengan selesainya penelitian ini saya mengucapkan terima kasih yang sebesarbesarnya kepada Allah Swt, kedua orang tua, kedua dosen pembimbing yaitu Ibu Isna Apriani, S.T, M.Si dan Ibu Ulli Kadaria, S.T, M.T serta kepada teman-teman Teknik Lingkungan 2012 dan semua orang yang telah berperan dalam membantu penelitian yang tidak dapat di ucapkan satu persatu. Harapan saya penelitian ini dapat bermanfaat bagi semua dan dapat dipergunakan sebagaimana mestinya.

\section{Daftar Pustaka}

Azamia, M. 2012. "Pengolahan Limbah Cair Laboratorium Kimia Dalam Penurunan Kadar Organik Serta Logam Berat Fe, Mn, Cr Dengan Metode Koagulasi dan Adsorpsi”. FMIPA. UI. Jakarta.

Aziz, T, Pratiwi, Y, Dwi, Rethiana, L. 2013. "Pengaruh Penambahan Tawas $\left(\mathrm{Al}_{2}\left(\mathrm{SO}_{4}\right)_{3}\right.$ dan Kaporit $\mathrm{Ca}(\mathrm{OCl})_{2}$ Terhadap Karakteristik Fisik dan Kimia Air Sungai Lambidaro". Universitas Sriwijaya. Palembang.

Fajarwati, I. 2015. "Pengolahan Air Tanah Dengan Sistem Multifiltrasi Menggunakan Cangkang Kerang, Zeolit, Dan Karbon Aktif". Jurnal Mahasiswa S1 Teknik Lingkungan: Vol. 1, No. 1. UNTAN. Pontianak.

Hendra, R. 2008. "Pembuatan Karbon Aktif Berbahan Dasar Batubara Indonesia Dengan Metode Aktivasi Fisika Dan Karakteristiknya". Departemen Teknik Mesin. UI. Jakarta.

Iswanto, W.N.A.; Moelyaningrum, A.D.; dan Pujiati, R.S. 2016. "Penurunan Kadar Logam Timbal Pada Limbah Cair Percetakan Dengan Zeolit Alam Teraktivasi (Studi Pada Limbah Cair Percetakan X Jember)". Jember.

Khimayah. 2015. "Variasi Diameter Zeolit Untuk Menurunkan Kadar Besi (Fe) Pada Air Sumur Gali”. Universitas Diponegoro. Semarang. 
Larasati, I.A.; Susanawati, D.L.; dan Suharto, B. 2014. "Efektifitas Adsorpsi Logam Berat Pada Air Lindi Menggunakan Media Karbon Aktif, Zeolit, dan Silika Gel Di TPA Tlekung, Batu". Jurnal Sumberdaya Alam dan Lingkungan. Malang.

Nurlina.; Zahra, T.A.; Gusrizal; dan Kartika, I.D. 2015. "Efektivitas Penggunanaan Tawas Dan Karbon Aktif Pada Pengolahan Limbah Cair Industri Tahu". Prosiding SEMIRATA 2015 Bidang MIPA BKS-PTN Barat. Hal. 690-699. Universitas Tanjungpura. Pontianak.

Setiaka, J; Ulfin, I; dan Widiastuti, N. 2010. "Adsorpsi lon Logam Cu (II) Dalam Larutan Pada Abu Dasar Batu Bara Menggunakan Metode Kolom". Prosiding Kimia FMIPA. ITS. Surabaya.

Susanawati, D.L.; Bambang, S.; dan Kustamar. 2011. "Penurunan Kandungan Logam Berat Pada Air Lindi Dengan Media Zeolit Menggunakan Metode Batch Dan Metode Kontinyu". Jurnal AGROINTEK. Vol. 5, No. 2. Malang.

Sutapa, I.D.A. 2014. "Perbandingan Efisiensi Koagulan Poli Alumunium Khlorida Dan Alumunium Sulfat Dalam Menurunkan Turbiditas Air Gambut Dari Kabupaten Katingan Provinsi Kalimantan Tengah". Ris. Geo. Tam Vol. 24, No. 1 (12-21). Bogor.

Wardhani, E.; Dirgawati, M.; dan Astadipura, D.F. 2012. Tugas Akhir: "Penentuan Jenis dan Dosis Koagulan dalam Mengolah Air Limbah Industri Penyamakan Kulit". Itenas. Bandung. 